\title{
PENGGUNAAN MEDIA SOSIAL TERSTRUKTUR SEBAGAI MEDIA BELAJAR MANDIRI MAHASISWA FAKULTAS KEDOKTERAN UNIVERSITAS MUHAMMADIYAH SUMATERA UTARA
}

Ratih Yulistika Utami ${ }^{1}$, Febrina Dewi Pratiwi ${ }^{2}$, Aril Rizaldi ${ }^{3}$

${ }^{1}$ Unit Pendidikan Kedokteran, Fakultas Kedokteran,UMSU

${ }^{2}$ Departemen Ilmu Kesehatan Kulit dan Kelamin, Fakultas Kedokteran, UMSU

${ }^{3}$ Departemen Ilmu Bedah Fakultas Kedokteran UMSU

ratihyulistika@umsu.ac.id

\begin{abstract}
Abstrak
Pendahuluan: Perkembangan teknologi saat ini merangsang setiap individu untuk memapu memanfaatkan teknologi dalam aspek kehidupan termasuk pendidikan kedokteran. Penggunaan media sosial bisa dilakukan oleh tiap individu secara mandiri sehingga apabila digunakan dalam proses pendidikan mampu merangsang kemmapuan belajar mandiri mahasiswa. Metode: Penelitian ini merupakan penelitian kuantitatif berupa penelitian eksperimen dengan rancangan pretest posttest control group. Populasi mahasiswa adalah mahasiswa FK UMSU angkatan 2016 pada blok urology and kidney. Cara pengambilan sampel mahasiswa dilakukan dengan metode simple random sampling. Jumlah sampel adalah 72 yaitu 36 orang untuk kelompok kontrol dan 36 orang untuk kelompok perlakuan. Hasil: Dari hasil uji independent t-test didapatkan bahwa tidak terdapat perbedaan nilai ujian blok urologi anatara kelompok intervensi dan kelompok kontrol dengan nilai $\mathrm{p}>0,05$. Dari hasil uji independent t-test didapatkan bahwa tidak ada perbedaan self-directed learning mahasiswa kelompok kontrol dan intervensi dengan nilai $\mathrm{p}>0,05$
\end{abstract}

Kata kunci: social media, self directed learning, self study

\begin{abstract}
Introduction: Current technological developments stimulate every person to use technology in aspects of life including medical education. The use of social media can be done by each individual independently so that when used in the education process can stimulate the ability of students to learn independently. Method: This research is a quantitative study in the form of an experimental study with a pretest posttest control group design. The student population is the 2016 UMSU Faculty of Medicine students in the urology and kidney block. The way to take student sample is done by simple random sampling method. The number of samples was 72 namely 36 people for the control group and 36 people for the treatment group. Results: From the results of the independent $t$-test it was found that there was no difference in the score of the urology block between the intervention group and the control group with $p>0.05$. From the results of the independent $t$-test it was found that there were no differences in the self-directed learning of control and intervention students with $p>0.05$.

Keywords: social media, self directed learning, self study

Pendahuluan
\end{abstract}


Sejak awal tahun 2000, media sosial menjadi bagian utama dalam kegidupan sehari-hari, namun pada dekade belakangan ini baru digunakan dalam pendidikan kedokteran ${ }^{1}$. Sehubungan dengan pertumbuhan eksponensial media sosial, fakultas kedokteran mengamati peningkatan pelamar dari Net Generation ${ }^{2}$. Ini adalah individu yang telah terpapar teknologi digital sejak usia muda dan, untuk mayoritas, menggunakan media sosial setiap hari atau bahkan sebagai sumber informasi utama mereka ${ }^{1}$.

Hasil survei oleh Avci et al (2009) menunjukkan bahwa 93,4\% mahasiswa kedokteran menggunakan media sosial dan $89,3 \%$ menggunakan media sosial tersebut untuk tujuan profesional. Satu per tiga orang dewasa telah menggunakan internet untuk menegakkan diagnosis penyakit ${ }^{3}$. Satu per tiga orang mengakses internet untuk melihat blog, grup daring, dan situs yang memberikan informasi pengalaman medis orang lain, dan $6 \%$ nya berkontribusi dengan memberikan komentar, pesan, foto, pesan suara, dan penialain medis dari dokter atau rumah sakit ${ }^{4}$. Dokter juga mengalami peningkatan dalam penggunaan media sosial dalam kehidupan profesi maupun sehari-hari ${ }^{5}$.

Penggunaan media sosial meningkatkan pendidikan kedokteran dengan melibatkan mahasiswa dalam membangun pengetahuan mereka sendiri secara eksplisit dan dengan memfasilitasi keterlibatan, refleksi diri dan pembelajaran aktif (self directed learning). Misalnya, mahasiswa kedokteran dapat menggunakan Facebook atau Google+ untuk kolaborasi grup daring, berbagi sumber daya dan dukungan moral sesama mahasiswa ${ }^{6}$.

Penggunaan media sosial bermanfaat ketika diintegrasikan ke dalam kurikulum pendidikan dokter. Platform media sosial memungkinkan umpan balik yang lebih cepat antara mahasiswa dan anggota fakultas di dalam dan di luar kelas secara mandiri ${ }^{7,8}$. Ini meningkatkan kecepatan akses informasi sehingga meningkatkan sehingga meningkatkan efisiensi pembelajaran. Media sosial adalah 
proses yang lebih aktif daripada kuliah didaktik tradisional. Mereka merasa lebih percaya diri dalam hal pengetahuan dan lebih siap untuk mendiskusikan topik dan berbagi pemikiran mereka ${ }^{8}$. Peningkatan keterlibatan pelajar dan interaktivitas yang dirangsang antara mahasiswa, yang pada gilirannya menghasilkan lebih banyak konten dan pada akhirnya meningkatkan nilai ${ }^{7}$.

Penelitian sebelumnya menjelaskan bagaimana media sosial telah membantu menciptakan Personal Learning Environments (PLEs). Ini adalah pendekatan pembelajaran yang dirancang oleh mahasiswa yang menggabungkan berbagai alat (video, aplikasi, game, gambar) yang dipilih oleh mahasiswa untuk menyesuaikan gaya belajar dan kecepatan pribadi mereka. Tujuannya adalah agar mahasiswa memiliki jumlah kontrol yang lebih besar atas cara mereka belajar. Misalnya, pelajar visual akan mendapatkan lebih banyak dari menonton video di YouTube daripada mendengarkan dalam ceramah $^{9}$. Penelitian lain menemukan bahwa mahasiswa tampil lebih baik ketika mereka bertanggung jawab atas pembelajaran mereka ${ }^{10}$.

Tinjauan sistematis menunjukkan bahwa mengajar mahasiswa bagaimana menggunakan media sosial adalah persiapan yang baik untuk kehidupan profesional mahasiswa. Ketika dunia menjadi lebih saling terhubung, penggunaan media sosial global adalah keterampilan yang perlu dikuasai oleh dokter masa depan ${ }^{8}$. Media sosial perlahan menjadi andalan profesi medis. Oleh karena itu, ada anggapan bahwa siswa harus diajarkan bagaimana menggunakannya secara profesional untuk memprioritaskan manfaat sekaligus membatasi setiap komplikasi atau efek yang tidak menguntungkan ${ }^{11}$. Tujuan penelitian ini adalah untuk: 1) menganalisis persepsi mahasiswa terhadap kemampuan self directed learning sebelum dan sesudah belajar mandiri menggunakan media sosial terstruktur, 2) menganalisis persepsi mahasiswa terhadap kemampuan self directed learning antara mahasiswa yang belajar mandiri menggunakan 
media sosial terstruktur dan mahasiswa yang tidak menggunakan media sosial, 3) menganalisis hasil ujian blok antara mahasiswa yang belajar mandiri menggunakan media sosial terstruktur dan mahasiswa yang tidak menggunakan media sosial, 4) menjelaskan gambaran persepsi mahasiswa terhadap penggunaan media sosial terstruktur pada belajar mandiri.

\section{Metode}

Penelitian ini merupakan penelitian kuantitatif berupa penelitian eksperimen dengan rancangan pretest posttest control group. Populasi mahasiswa adalah mahasiswa FK UMSU angkatan 2016 pada blok urology and kidney. Cara pengambilan sampel mahasiswa dilakukan dengan metode simple random sampling. Jumlah sampel adalah 72 yaitu 36 orang untuk kelompok kontrol dan 36 orang untuk kelompok perlakuan.

Instrumen yang digunakan pada penelitian ini adalah Kuesioner SDLR untuk menilai persepsi mahasiswa terhadap kemampuan self directed learning, sedangkan untuk menilai hasil ujian mahasiswa digunakan soal MCQ pada ujian blok. Penelitian ini juga menilai persepsi mahasiswa terhadap pengalaman belajar mandiri menggunakan media sosial ini menggunakan kuesioner yang dikembangkan oleh peneliti sendiri. Media sosial yang digunakan adalah grup whatssap dan instagram untuk mendiskusikan kasus dan membuat kesimpulan kasus.

Penelitian ini dilakukan dalam beberapa tahap, yaitu: pengurusan ethical clearence. Penelitian ini sudah mendapatkan izin dari Komite Etik Penelitian Kesehatan FK UMSU No.236/KEPK/FKUMSU/2019， 2) pembuatan panduan penggunaan media sosial pada pembelajaran mandiri terstruktur, 3) peneliti menjelaskan tujuan dan tahapan penelitian kemudian meminta persetujuan subjek penelitian dan ahli untuk mejadi fasilitator, 4) peneliti membagikan kuesioner mengenai persepsi mahasiswa terhadap self directed learning dan penggunaan media sosial pada pembelajaran mandiri terstruktur, 5) 
memberikan perlakuan. Perlakuan diberikan selama blok urology selama 4 minggu efektif. Peneliti meminta ahli untuk bergabung di media sosial grup dan mengundang mahasiswa kelompok intervensi ke dalam grup. Ahli berperan sebagai fasilitator untuk memberikan kasus dan pertanyaan agar mahasiswa terangsang untuk mendiskusikan kasus. Setiap mahasiswa berhak untuk memberikan kasus untuk didiskusikan bersama juga, 5) peneliti mengumpulkan data. Pengumpulan data persepsi mahasiswa setelah perlakuan dan mengumpulkan nilai blok dari divisi assessmen, 6) peneliti mengolah dan analisis data serta membuat kesimpulan.

\section{Hasil}

Tabel 1. Data demografi responden

\begin{tabular}{lccc}
\hline Indeks & Jenis & Tot & Nil \\
prestas & kelamin & al & ai \\
i & & & p \\
kumul & & & \\
atif & & & \\
\hline & Perem & Laki & 0,2 \\
& puan & -laki & 57 \\
\hline
\end{tabular}

\begin{tabular}{llll}
\hline & $\mathrm{F}(\%)$ & $\mathrm{F}(\%$ & $\mathrm{F}(\%$ \\
& & ) & ) \\
\hline Memua & 7 & 8 & 15 \\
skan & $(10,30)$ & $(11$, & $(22$, \\
& & $76)$ & $06)$ \\
\hline Sangat & 30 & 17 & 47 \\
memua & $(44,12)$ & $(25)$ & $(69$, \\
skan & & & $12)$ \\
\hline Dengan & 5 & 1 & 6 \\
pujian & $(7,35)$ & $(1,4$ & $(8,8$ \\
& & $7)$ & $2)$ \\
\hline & 42 & 26 & 68 \\
& $(61,76)$ & $(38$, & $(100$ \\
& & $24)$ & )
\end{tabular}

Dari data di atas dijumpai bahwa 47 responden memiliki indek prestasi kumulatif (IPK) sangat memuaskan, 30 di antara nya adalah perempuan dan 17 orang laki-laki. Mahasiswa yang memiliki IPK memuaskan 15 orang, laki-laki lebih banyak 1 orang dibandingkan dengan laki-laki. Mahasiswa dengan IPK dengan pujian sebanyak 6 orang dan hanya 1 orang berjenis kelamin laki-laki. Karakteristik antara kelompok kontrol dan kelompok intervensi tidak ada perbedaan atau homogen. 
Tabel 2. Perbedaan nilai ujian blok kelompok kontrol dan intervensi

\begin{tabular}{lccl}
\hline Kelo & Mean & $\begin{array}{c}\text { Std. } \\
\text { Devia }\end{array}$ & Nilai p \\
mpok & & si & \\
& & 14,49 & \\
\cline { 1 - 2 } Inter & 55,59 & 0,085 \\
vensi & & & \\
\cline { 1 - 2 } Kontr & 61,62 & 13,94 & \\
ol & & & \\
\hline
\end{tabular}

Dari hasil uji independent t-test didapatkan bahwa tidak terdapat perbedaan nilai ujian blok urologi anatara kelompok intervensi dan kelompok kontrol dengan nilai p> 0,05 , namun responden menganggap bahwa intervensi yang dilakukan baik dan dapat merangsang kemapuan belajar mandiri mahasiswa seperti ditunjukkan pada tabel 4 .

Tabel 3. Perbedaan persepsi selfdirected learning kelompok kontrol dan intervensi

\begin{tabular}{cccl}
\hline Kelo & Mean & $\begin{array}{c}\text { Std. } \\
\text { mpok }\end{array}$ & \multicolumn{3}{c}{ Nilai p } \\
& \multicolumn{3}{c}{ Devia } \\
& \multicolumn{3}{c}{ si } \\
\hline Inter & 147,6 & 15,92 & 0,374 \\
vensi & 5 & & \\
\end{tabular}

\begin{tabular}{lcc}
\hline Kontr & 151,2 & 17,13 \\
ol & 4 & \\
\hline
\end{tabular}

Dari hasil uji independent t-test didapatkan bahwa tidak ada perbedaan self-directed learning mahasiswa kelompok kontrol dan intervensi dengan nilai $\mathrm{p}>0,05$. Rerata skor self-directed learning kelompok kontrol lebih tinggi 3,59 dibandingkan dengan kelompok intervensi.

Tabel 4. Gambaran persepsi mahasiswa tentang pengalaman belajar mandiri terstruktur dengan media sosial

\begin{tabular}{llllll}
\hline Perseps & Sa & Set & Ne & Ti & Sa \\
i & ng & uj & tra & da & ng \\
& at & u & l & k & at \\
& set & & & set & tid \\
& uju & & & uj & ak \\
& & & & u & set \\
& & & & & uju \\
\hline 1. Grup & 7 & 2 & 1 & 0 & 0 \\
disk & & & & & \\
usi & & & & & \\
blok & & & & & \\
urol & & & & & \\
ogi & & & & & \\
berm & & & & & \\
\end{tabular}




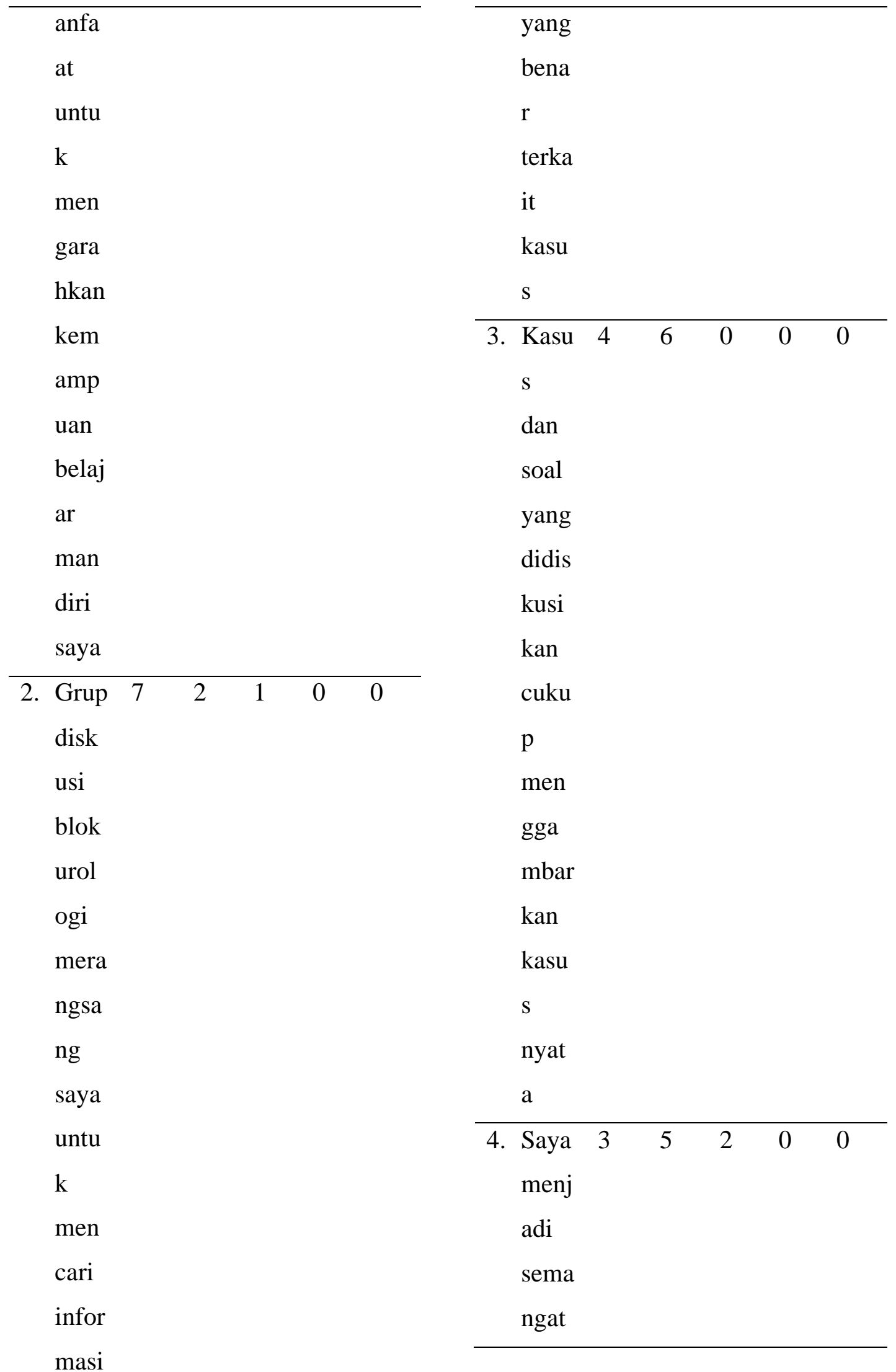




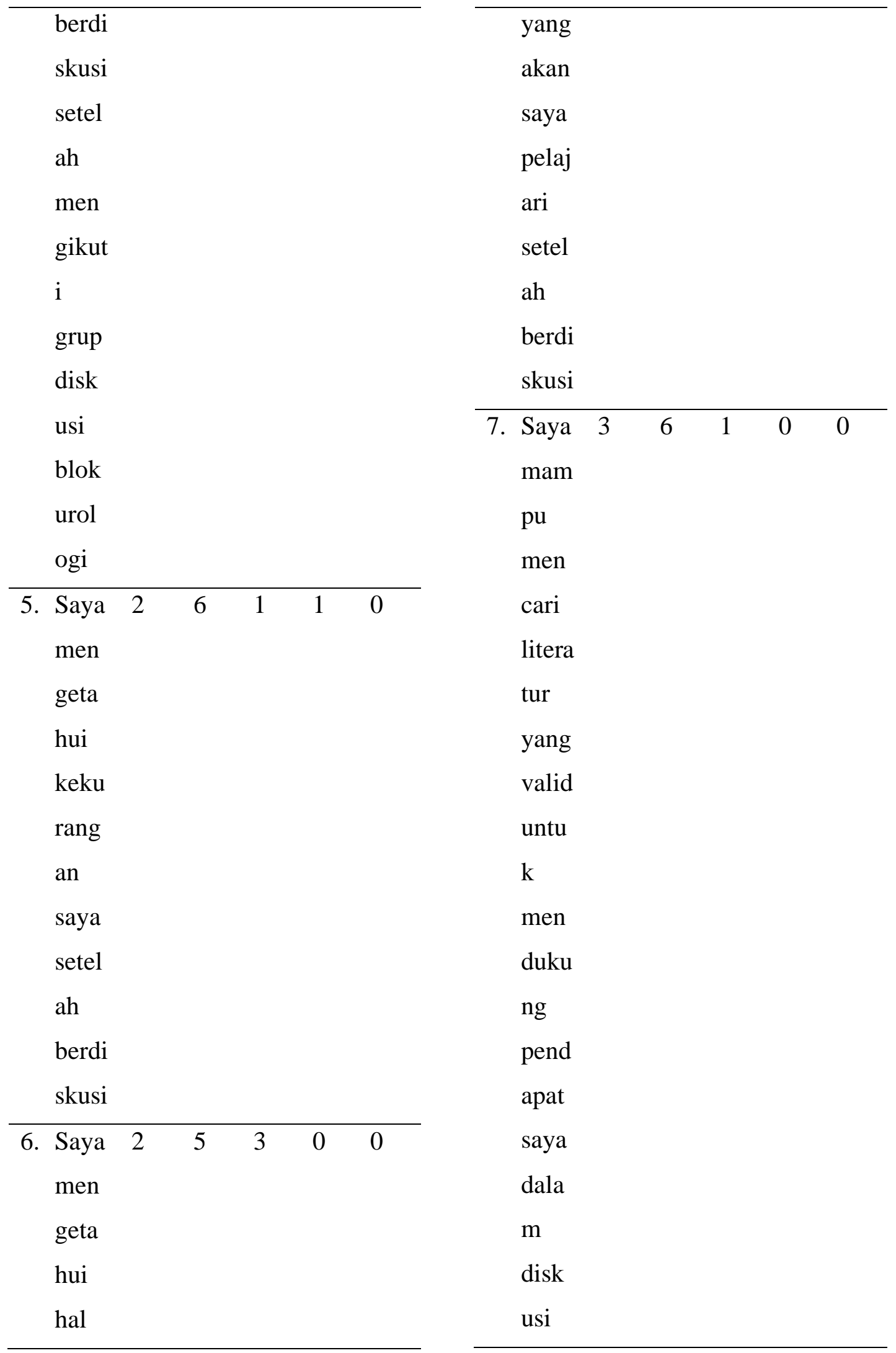




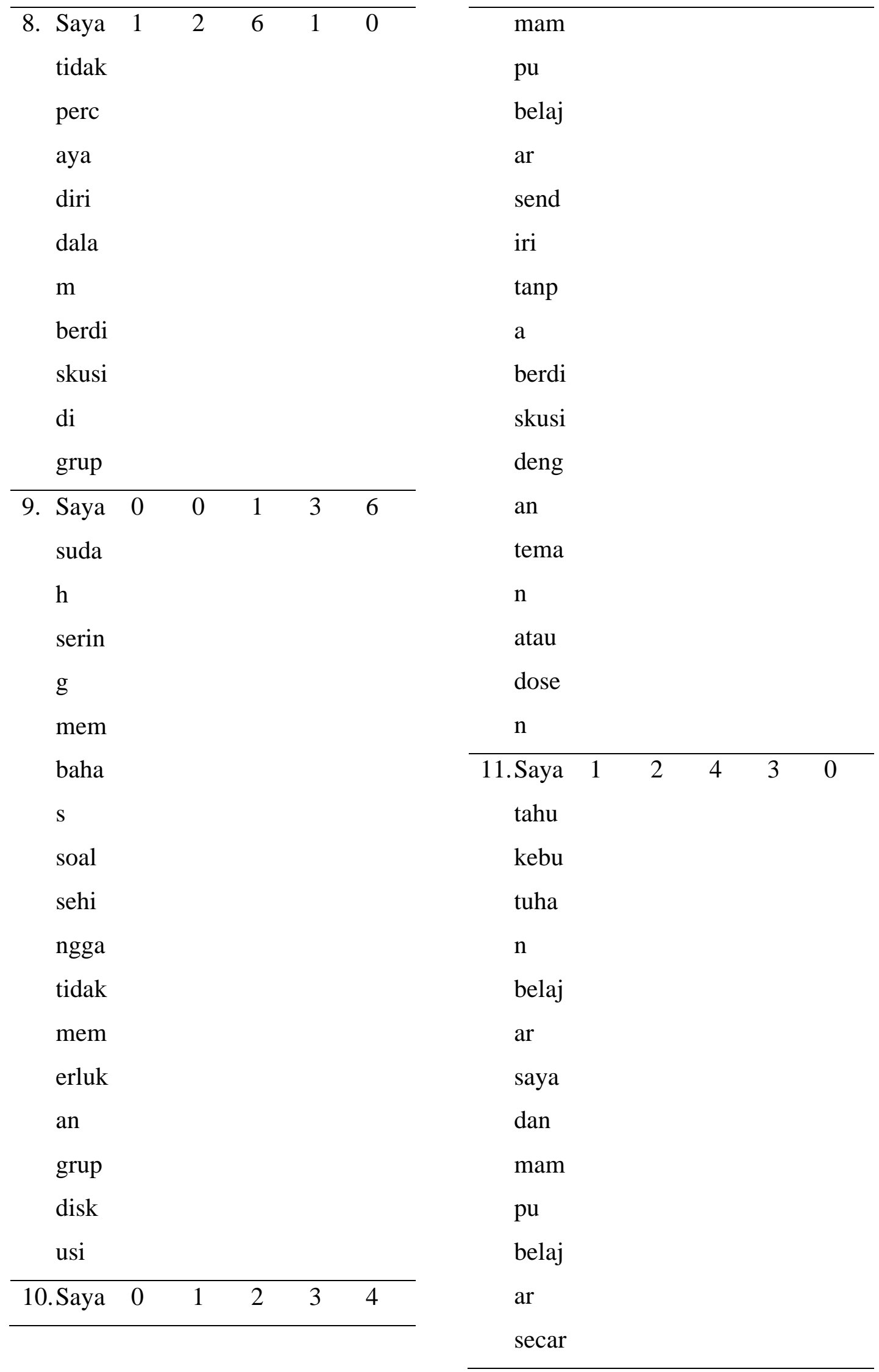




\begin{tabular}{|c|c|c|c|c|c|}
\hline $\begin{array}{l}\text { a } \\
\text { man } \\
\text { diri }\end{array}$ & & & & & \\
\hline $\begin{array}{l}\text { 12.Berd } \\
\text { iskus } \\
\mathrm{i} \\
\text { meni } \\
\text { ngka } \\
\text { tkan } \\
\text { kem } \\
\text { amp } \\
\text { uan } \\
\text { berpi } \\
\text { kir } \\
\text { kritis } \\
\text { saya }\end{array}$ & 5 & 4 & 1 & 0 & 0 \\
\hline $\begin{array}{l}\text { 13. Saya } \\
\text { men } \\
\text { yuka } \\
\text { i } \\
\text { meto } \\
\text { de } \\
\text { belaj } \\
\text { ar } \\
\text { disk } \\
\text { usi } \\
\text { deng } \\
\text { an } \\
\text { tekn } \\
\text { ologi }\end{array}$ & 2 & 4 & 4 & 0 & 0 \\
\hline
\end{tabular}

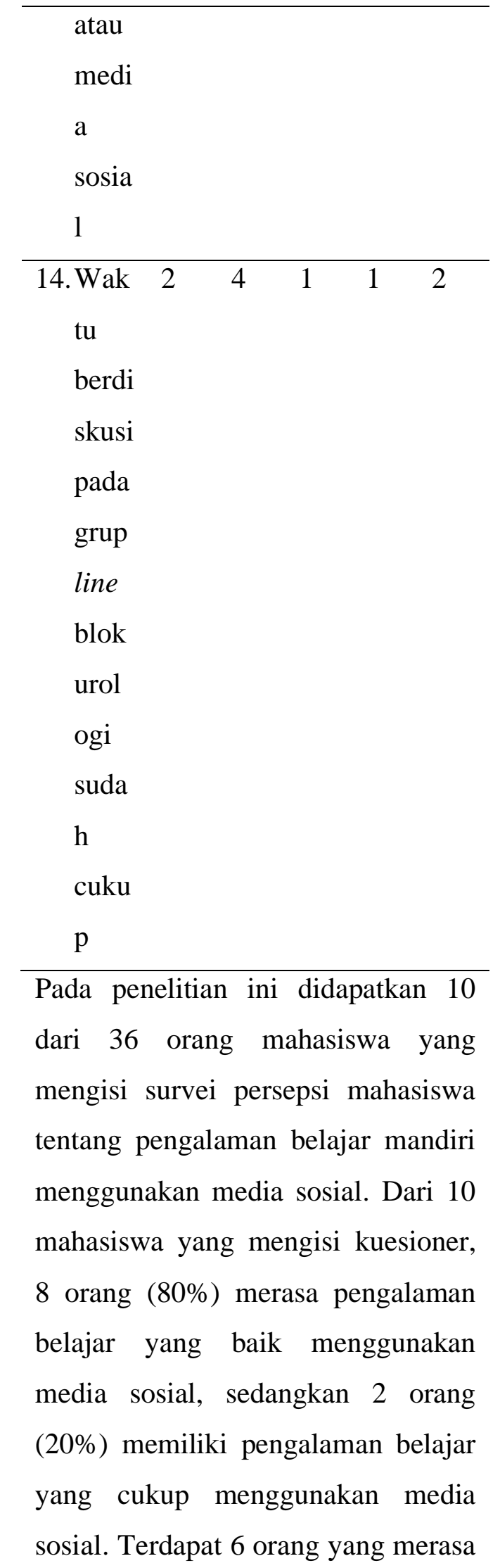


kurang percaya diri dalam berdiskusi di grup.

\section{Diskusi}

Penelitian ini menunjukan tidak ada perbedaan nilai ujian dan persepsi self-directed learning antara kelompok yang mendapatkan perlakuan dengan kelompok kontrol. Penggunaan media sosial cukup banyak, namun dampaknya masih belum jelas ${ }^{12}$. Penelitian sebelumnya menunjukan hubungan negatif antara penggunaan berbagai jenis media elektronik dengan nilai mahasiswa. Hal tersebut disebabkan oleh dua hal: 1) mahasiswa tidak menggunakan teknologi untuk tujuan akademik meskipun menguasai berbagai jenis teknologi. Penelitian menunjukan bahwa meskipun mahasiswa merupakan digital native yang sangat mahir dan pandai dalam keterampilan praktis seperti bermain game, media sosial, berkirim pesan, dan mencari informasi, namun hal tersebut tidak bisa menjadi indikator yang reliabel bahwa mereka memanfaatkan keterampilan tersebut untuk tujuan akademis ${ }^{13,14,15}$, dan 2) penggunaan teknologi yang sering dan multitasking menyebabkan gangguan dan kekurangan waktu untuk tugas akademik.

Penelitian lain yang sejalan menemukan korelasi negatif antara penggunaan teknologi dengan prestasi akademik. Beberapa faktor seperti kognitif, kontekstual, sosial, dan ekologis mempengaruhi hubungan tersebut ${ }^{16}$. Meskipun mahasiswa termotivasi, terlibat dan mahir menggunakan teknologi modern, namun penting untuk merancang pembelajaran yang bertujuan tidak hanya untuk meningkatkan keterlibatan siswa, tetapi juga pengembangan diri, yang mengarah pada peningkatan prestasi akademik $^{17}$, dan dosen harus mempertimbangkan cara mengintegrasikan teknologi yang meningkatkan pembelajaran dan pemikiran kritis $^{18,19}$. Tanpa pengawasan dari dosen, mahasiswa yang belajar sendiri mungkin akan mengalami kesalahan atau ketidakpastian saat mempraktikkan keterampilan ${ }^{20}$. Pembelajaran yang diintegrasikan dengan teknologi akan menguntungkan mahasiswa melalui dua cara: 1) mahasiswa menjadi 
penerima pengetahuan dan pembelajar aktif, dan 2) mahasiswa menjadi lebih bertanggung jawab atas pembelajaran mereka sendiri ${ }^{21}$.

Penelitian lain yang bertolak belakang dengan hasil penelitian sebelumnya menyatakan bahwa penggunaan sosial media sebagai prediktor positif keterlibatan mahasiswa, kemampuan belajar mandiri, dan prestasi mahasiswa ${ }^{22}$. Pada penelitian ini didapati mahasiswa merasa bahwa metode ini dapat mengarahkan kemampuan belajar mandiri, kemampuan berpikir kritis dan kemampuan mencari literatur yang valid. Penelitian sebelumnya menyatakan bahwa pembelajaran yang membantu mahasiswa untuk memahami pertanyaan, menyampaikan pendapat, dan membagikan ide dan kesimpulan di antara mahasiswa lain $^{23}$.

Pembelajaran menggunakan media sosial memiliki keuntungan yaitu, 1) mahasiswa dapat memperoleh pengetahuan keseluruhan yang lebih besar, lebih banyak peluang komunikasi dosen dan mahasiswa. Mahasiswa mendiskusikan masalah dan mengekspresikan pendapat mereka. Dibandingkan dengan sistem pembelajaran tradisional, diskusi melalui media sosial mendorong mahasiswa untuk berinteraksi untuk memperkuat pembelajaran mereka dan menyelesaikan tugas secara mandiri dan aktif. Sistem ini juga berfungsi untuk memahasiswa dengan motivasi diri yang buruk. Gambar dan video sangat jelas sehingga mahasiswa dapat memahami materi secara menyeluruh. Jika mahasiswa memiliki pertanyaan, mereka dapat memberikan pesan dan dosen atau teman sebaya akan menjawab. Dosen dapat mengajar mahasiswa sesuai dengan bakat mereka sehingga meningkatkan efisiensi belajar. Dosen juga daoat menympaikan materi tanpa batasan waktu dan ruang. Di waktu senggang mereka, dosen dapat mengambil kasus-kasus tertentu, membuat pertanyaan, dan kemudian mengirimkannya di media sosial. Mahasiswa juga bisa mendiskusikan kasus di grup mereka sendiri sehingga pemecahan masalah dapat dilakukan dengan cepat. Hal 
ynag perlu dipertimbangkan untuk menggunakan media sosial dalam proses pembelajaran adalah jaringan internet dan kerahasiaan pasien apabila mengunggah video kasus atau data pasien. Untuk mengatasi masalah tersebut, data yang akan dibagikan harus mendapat persetujuan pasien dan maahsiswa dilarang membagikannya ke orang lain. Mahasiswa yang introvert dan acuh tak acuh jika menggunakan media sosial akan sedikit berbicara sama seperti dalam kehidupan nyata karena keterampilan sosial mereka yang kurang baik ${ }^{24}$.

\section{Belajar}

mandiri

membutuhkan karakteristik

mahasiswa, yaitu inisiatif untuk mengelola pembelajaran sendiri. Inisiatif termasuk mengenali kebutuhan belajar pribadi dan kemudian mengatur pendekatan untuk mencari dan menemukan informasi dan sumber daya untuk memenuhi kebutuhan belajar tersebut. Tantangan belajar mandiri adalah menemukan terlalu banyak informasi dan tidak tahu bagaimana menguraikan dan menyaring informasi secara efisien dalam waktu yang efektif. Penelitian lain menyatakan bahwa pembelajaran mandiri dapat mencakup jenis pembelajaran informal, nonformal, dan formal, dan sebagian besar pembelajaran ini bisa menggunakan teknologi (misal, berpartisipasi dalam program belajar jarak jauh). Temuan-temuan ini mendukung penelitian sebelumnya yang menunjukkan bentuk pembelajaran mandiri dapat dilakukan dengan berbagai $\operatorname{cara}^{25}$. Penelitian sebelumnya mengidentifikasi belajar mandiri yang melibatkan berbagai kegiatan dan sumber daya, seperti membaca mandiri, partisipasi dalam kelompok belajar, magang, dialog elektronik, dan kegiatan menulis refleksi diri ${ }^{26}$.

Penelitian ini juga menemikan bahwa mahasiswa merasakan kurang percaya diri sehingga mempengaruhi keaktifan mereka dalam dalam berdiskusi. Meskipun begitu, mahasiswa merasa waktu untuk berdiskusi cukup dan mahasiswa menyukai metode pembelajaran ini. Ketersediaan waktu merupakan faktor yang penting dalam mengembangkan 
kemampuan belajar mandiri. Faktor yang juga mempengaruhi kemampuan belajar mandiri adalah budaya, hirarki, dan pencapaian. Tipe pendidikan menengah yang dimiliki mahasiswa juga mempengaruhi kemampuan belajar mandiri. Perkembangan perilaku belajar mandiri mahasiswa tergantung pada kebutuhan mereka. Evaluasi diri dan kesadaran diri serta manjemen waktu juga penting untuk mengembangkan kemampuan belajar mandiri. ${ }^{27,28}$ Sedikit sekali mahsiswa yang berkunjung ke rumah sakit atas keinginan sendiri untuk belajar lebih banyak mengenai topik yang telah mereka pelajari di tahap akademik. Minat mahasiswa yang rendah tersebut karena tipe sekolah menengah yang $\operatorname{ada}^{29}$. Penelitian lain menunjukan bahwa kemampuan belajar mandiri mahasiswa tidak berkembang selama tahap akademik karena struktur kurikulum ${ }^{28}$.

\section{Kesimpulan}

Penggunaan media sosial pada proses pembelajaran direkomendasikan untuk dilakukan oleh dosen kepada mahasiswa terutama pada jumlah yang sedikit agar proses pembelajaran lebih efisien dan efektif serta dapat memfasilitasi kebutuhan belajar mahasiswa. Namun perlu dipertimbangkan kemampuan mahasiswa dalam berdiskusi, mencari dan menyaring informasi yang valid. Waktu seharusnya bukan menjadi kendala dalam pembelajaran menggunakan media sosial karena bias dilakukan kapan saja namun mahasiswa dan dosen juga memiliki kewajiban lain yang perlu diperhatikan sehingga sebaiknya dilakuakn secara terjadwal.

\section{Referensi}

1. Pander, T., Pinilla, S., Dimitriadis, K. and Fischer MR. 'The use of Facebook in medical education - A literature review', GMS Z Med Ausbild. 2014;31(3), Doc33. doi: 10.3205/zma000925.

2. Kennedy G, Gray K, Tse J. 'Net Generation' medical students: technological 
experiences of pre-clinical and clinical students. Med Teach. 2008;30(1):10-16.

3. Fox S, Duggan M. Health Online. Pew Internet \& American Life Project. 2013. Available from

http://www.pewinternet.org/

$\underline{\text { Reports/2013/Health- }}$

online.aspx

4. Fox S. Peer-to-Peer Healthcare. Pew Internet \& American Life Project. (2011). Available from http://pewinternet.org/Report s/2011/P2PHealthcare.aspx

5. Mansfield SJ, Morrison SG, Stephens HO, Bonning MA, Wang SH, Withers AH, et al. Social media and the medical profession. Med J Aust. 2011 ;194(12):642-4.

6. Gray K, Annabell L, Kennedy G. Medical students' use of Facebook to support learning: insights from four case studies. Med Teach. 2010;32:971-6

7. Cheston, C.C., Flickinger, T.E. and Chisolm, M.S. 'Social media use in medical education', Academic Medicine. 2013; 88(6), pp. 893-901. doi: 10.1097/acm.0b013e31828ffc 23.

8. Hollinderbaumer A, Hartz T, Uckert F. Education 2.0 How has social media and Web 2.0 been integrated into medical education? A systematical literature review. GMS Z Med Ausbild. 2013; 30(1): Doc14.

9. Johnson, L., Adams, S., \& Haywood, K. The NMC horizon report: 2011 K-12 edition. Austin, Texas: The New Media Consortium. 2011. Available from http://www.nmc.org/pdf/2011 -Horizon-Report-K12.pdf

10. DiLullo, C., McGee, P. and Kriebel, R. Demystifying the Millennial student: A reassessment in measures of character and engagement in professional education. Anatomical Sciences Education. 2011; 4(4), pp.214-226. 
11. Kind, T., Patel, P., Lie, D. and Chretien, K. Twelve tips for using social media as a medical educator. Medical Teacher. 2014; 36(4), pp.284290.

12. Sutherland, S., Jalali, A. Social media as an openlearning resource in medical education: current perspectives. Advances in Medical Education and Practice. 2017:8 369-375.

13. Gurung, B., \& Rutledge, D. Digital learners and the overlapping of their personal and educational digital engagement. Computers \& Education. 2014;77, 91-100. http://dx.doi.org/10.1016/j.co mpedu.2014.04.012.

14. Rowlands, I., Nicholas, D., Williams, P., Huntington, P., Fieldhouse, M., Gunter, B., et al. The Google generation: the information behaviour of the researcher of the future,. Aslib Proceedings, 2008;60(4), 290e310.

15. Selwyn, N. Faceworking: exploring students' education-related use of Facebook. Learning, Media and Technology, 2009;34(2), 157-174.

http://dx.doi.org/10.1080/174 39880902923622.

16. Lepp, A., Barkley, J. E., \& Karpinski, A. C. The relationship between cell phone use, academic performance, anxiety, and Satisfaction with Life in college students. Computers in Human Behavior, 2014 31, 343-350.

http://dx.doi.org/10.1016/j.ch b.2013.10.049.

17. Hyland, N., \& Kranzow, J. Faculty and student views of using digital tools to enhance self-directed learning and critical thinking. International Journal of Self-Directed Learning, 2011;8(2), 11-27.

18. Facione, P., \& Facione, N. Thinking and reasoning in human decision making: The method of argument and heuristic analysis. Millbrae, CA: The California Academic Press. 2007. 
19. Prensky, M. Digital natives, digital immigrants part 1 . On the Horizon, 2001;9(5), 1-6. http://dx.doi.org/10.1108/107 48120110424816.

20. Mcgrath, D., Crowley, L., Rao, S., Toomey, M., Hannigan, A., Murphy, L., et al. Outcomes of Irish graduate entry medical student engagement with selfdirected learning of clinical skills. BMC Medical Education, 2015;15(1), 21. http://dx.doi.org/10.1186/s12 909-015-0301-x.

21. Wang, T. The transformational promise of information and communications technologies (ICTs) for the professional education of architects. Educational Technology \& Society, 2009;12(3), 206-213. 22. Rashid, T., Asghar HM. Technology use, self-directed learning, student engagement and academic performance: Examining the interrelations. Computers in Human Behavior, 2016:63. p.604-
612.

http://dx.doi.org/10.1016/j.ch b.2016.05.084.

23. Bender T. Discussion-based online teching to enhance student learning: Theory, Pratice adnAssessment. Sterling: Stylus Pbulishing. 2003.

24. Furong Zeng, Guangtong Deng, Zhao Wang, Longfei Liu. WeChat: a new clinical teaching tool for problembased learning. International Journal of Medical Education. 2016;7:119-121. ISSN: 2042-6372. DOI: 10.5116/ijme.5708.e5c4.

25. Curran V., Gustafson DL., Simmons K., Lannon H., Wang C., Garmsiri M. Adult learners' perceptions of selfdirected learning and digital technology usage in continuing professional education: An update for the digital age. Journal of Adult and Continuing Education, 2019:0(0), p.1-20

26. Hiemstra, R., \& Brockett, R. G. Reframing the meaning of 
self-directed learning. Adult

Education

Research

Conference Proceedings.

2012. Retrieved from

http://newprairiepress.org/cgi

$\underline{\text { /viewcontent.cgi? } \text { article }=307}$

$\underline{0 \& \text { context }=\text { aerc }}$

27. Frambach JM, Driessen EW,

Chan LC, van der Vleuten

CP. Rethingking the globalization of problembased learning: how culture challenges self-directed learning. Med Educ. 2012;46:p.738-747.

28. Lucieer SM, van der Geest JN, Eloi-Santos SM, de Faria
RMD, Jonker L, Visscher C, et al. The development of self-regulated learning during the pre-clinical stage of medical school: A comparison between a lecture-based and a problembased curriculum. Adv in Health Sci Edu. 2016; 21(1): 93-104.

29. Shrish P, Manjunath SM, Nidoni M, Raju N. Utility of Web 2.0tools for self-directed learning among first year MBBS Students. National Journal of Clinical Anatomy. 2017;6(3): 208-214 